\title{
Impact of Potassium Fertilization Rates and Bacillus circulans on the Growth, Yield and Color of processed Potato (Solanum tuberosum L.) Tubers Chips
}

\author{
Said A. Z. Elhakim ${ }^{1}$, Dina, S. El-Mesirry ${ }^{2}$ and Mona, M. Yousry ${ }^{3}$
}

\begin{abstract}
Two field experiments were conducted during the winter seasons of $2014 / 2015$ and $2015 / 2016$ at ELNobarayaRigion $71 \mathrm{~km}$, Alex-Cairo desert road, atChipsy Company farm in Beheira Governorate. This investigation aimed to study the effect of BacilliusCirculans (potassium bio fertilizers)in combination with different rates of mineral potassium on the growth, yield and quality characters. Potassium fertilizer at levels 80 and $100 \mathrm{~kg} / \mathrm{fed}$. with application of bio- fertilizer gave the highest mean number of branches. It was also equivalent to the application of $\mathrm{K}$ fertilizer only at $120 \mathrm{~kg} / \mathrm{fed}$, or with application of bio-fertilizer but potassium application at $100 \mathrm{~kg} / \mathrm{fed}$, gave the best results ofplantheight equivalent to the application of Kfertilizer only at $120 \mathrm{~kg} / \mathrm{fed}$, or with application of bio-fertilizer while. The application of $\mathrm{K}$ fertilizer only at $120 \mathrm{~kg} / \mathrm{fed}$, or with application of biofertilizer gave the highest mean value of total clorophll. Moreover, potassium application at level $100 \mathrm{~kg} / \mathrm{fed}$,gave the highest mean value of tuber weight(ton)/fed, average tuber weight(kg) dry matter, specific gravity and accepted potato yield for processingequivalent to the application of $k$ fertilizer only at $120 \mathrm{~kg} / \mathrm{fed}$, or with application of biofertilizer. The application of $\mathrm{K}$ fertilizer only at $60 \mathrm{~kg} / \mathrm{fed}$, or with application of bio-fertilizer gave the highest mean number of tuber. Addition of $\mathrm{K}$ fertilizer only at $60 \mathrm{~kg} / \mathrm{fed}$, gave the highest mean value of nitrogen concentration in leaves and roots.Application of $K$ fertilizer only at 120 $\mathrm{kg} / \mathrm{fed}$, or with application of biofertilizer gave the highest mean value of $K$ concentration in leaves and tuber. Potassium application at $100 \mathrm{~kg} / \mathrm{fed}$, gave the highest mean value of starch content equivalent to the application of $K$ fertilizer only at $120 \mathrm{~kg} / \mathrm{fed}$, or with applicationof biofertilizer. Application of $\mathrm{K}$ fertilizer only at $60 \mathrm{~kg} / \mathrm{fed}$, gave the highest mean value of total sugar and reducing sugar. The lowest level of chips defects was also found at the level $120 \mathrm{~kg} \mathrm{~K} / \mathrm{fed}$, only or with application of bio-fertilizer. Potassium at $100 \mathrm{~kg} / \mathrm{fed}$, with application of bio-fertilizer gave the same effect in the two seasons.
\end{abstract}

Key words: potatoes; potassium fertilization; BacillusCirculans.

\section{INTRODUCTION}

One of the most important solanaceous vegetable crops grown in Egypt is potato (Solanum tuberosum L.). Its tubers are rich in carbohydrates and contain considerable amounts of proteins, vitamins and minerals. Potato is fourth most important world crop, after rice, wheat and maize (Spooner and Bamberg, 1994). It is a major source of inexpensive energy. It contains high levels of carbohydrates and significant amount of vitamin Band $\mathrm{C}$ and other minerals, each $100 \mathrm{~g}$ of edible portion of the tuber contains $79.89 \mathrm{~g}$ water, 76 calories, 2.1 protein, $0.19 \mathrm{~g}$ lipids, $17.19 \mathrm{~g}$ carbohydrates, $0.5 \mathrm{~g}$ fibers, $0.9 \mathrm{mg}$ ashes, $7 \mathrm{mg}$ calcium, $53 \mathrm{mg}$ phosphorus, $0.6 \mathrm{mg}$ iron, $3 \mathrm{mg}$ sodium, $407 \mathrm{mg}$ potassium,22 mg magnesium, traces of vitamin A, 0.1 $\mathrm{mg}$ thiamin, $0.4 \mathrm{mg}$ riboflavin, $1.5 \mathrm{mg}$ niacin, $20 \mathrm{mg}$ ascorbic acid (Watt and Merrill 1963). Moreover, potato is used in many industries, such as French fries, chips starch and alcohol production (Abdel-Aal, et.al., 1977). Now in Egypt, a great part of potato crop directed to chips production to supply the Egyptian and foreign market throughout the year. The chipping companies complain about the discoloration of the product due to the high reducing sugars even after a considerable storage time after harvesting. Potato has a high potassium requirement that could be attributed to: poorly developed root system (Abdel salam and Shams (2012). Saurbeck and Helal (1990) declared that potassium is necessary for many plant functions such as carbohydrate metabolism enzyme activation, $\mathrm{N}$ uptake, protein synthesis, photosynthesis and translocation of assimilates.

Potassium is usually applied in forms of chemical fertilizers mainly sulphate chloride and nitrate .In Egypt, $\mathrm{K}$ is added as sulphate. Recently, addition of these fertilizers has been criticized due to a suspicion of having an adverse effect on environment (Abdel salam and Shams (2012).

Some microorganisms play important roles in the weathering processes of silicate minerals through solubilizing nutrients (Deka and Dutta 2000; Lallitha et.al.,2000; Ahmed 1994 andMarschner1997). They added microorganisms which are commonly known as potassium solubilizing bacteria (KSP) or potassium dissolving bacteria (KDP) or silicate dissolving bacteria (SDP) solubilize K- bearing minerals to free $\mathrm{K}$ for plants.

\footnotetext{
${ }^{1}$ Agro farm manager.Chipsy for food industries.Pepsico

${ }^{2}$ Sabaheya Hort. Res.,Horticultural Research Institute,

Agriculture Research Center, Egypt.

${ }^{3}$ Plant production department, Faculty of Agriculture Saba Basha, Alex. University

Received September 27, 2016, , Accepted November 14, 2016
} 
The present investigation was initiated to study the effect of BacilliusCirculans as potassium bio-fertilizers in combination withdifferent rates of mineral potassium on the growth, yield and quality character of potato.

\section{MATERIALS AND METHODS}

Two field experiments were conducted at ELNobarayaRigionof $71 \mathrm{~km}$, Alex-Cairo desert road, Chipsy Company farm in Beheira Governorate, during the winter potato growing seasons of 2014/2015 and $2015 / 2016$. Some of the chemical properties of the experimental soil weredetermined before planting according to the methods outlined by Jackson (1973) and are shown in Table(1).

\section{Source of potato seedtubers and planting}

Local produced certified potatoseed tubers of Karozo cultivar were tested. Planting took place in the first of October of both seasons in a wet soil, using whole seed tubers. One hundred whole locally produced seed tubers were planted in two rows, $0.90 \mathrm{~m}$ wide, 12.5 $\mathrm{m}$ long and $0.25 \mathrm{~m}$ apart between hills, making an area of $22.5 \mathrm{~m}^{2}$ for each experimental plot.The experiments were laid out in a split plot design with three replicates.

\section{Field experiment}

Phosphorus fertilizer was applied at the rate of 46.5 $\mathrm{kg} \mathrm{P}_{2} \mathrm{O}_{5} / \mathrm{fed}$.in the form of superphosphate $(15.5 \%$ $\mathrm{P}_{2} \mathrm{O}_{5}$ ), added once in the opened row at planting time to all of the experimental plots. Nitrogen fertilizer was added at the rate of $150 \mathrm{~kg} \mathrm{~N} / \mathrm{fed}$., in four equal doses, the first one was added at soil preparation,the second, the third and the fourth doses were added at 30,45 and 60 days after planting in the form of ammonium nitrate $(33.5 \%)$. Fourpotassium levels were tested in this experiment $60,80,100$ and $120 \mathrm{~kg}$ (as a control) $\mathrm{K}_{2} \mathrm{O}$ /fed., which were added on three equal doses, the first one was during soil preparation and the $2^{\text {nd }}$ and $3^{\text {rd }}$ at 45 and 60 days after planting in the form of potassium sulphate $\left(48 \% \mathrm{~K}_{2} \mathrm{O}\right)$. Potato seeds were inoculated just before sowing with bio fertilizer (Bacillus Circulans) which is a commercial product obtained from Hanover, Germany, and it was added at the rate of $100 \mathrm{ml} / \mathrm{plant}$ (200 g powder /100 1 water as recommended).

\section{Frying experiment}

Random potato tuber samples were taken from each treatment either from cold storage or from nawalla in 15 days interval for chemical analysis. The first sample was taken at harvesting time, and then at 15, 30, 45, 60 and 75 days after harvesting from both storage facilities.Potato tuber were washed and cleaned by running water, peeled using carbarundum mechanical potato peeler model No 20 fimar Co., Italy, with size 14 lbs., grit size 1-1.5 mm for 1.5 to 2 minutes. Washed peeled potatoes were trimmed by hand using stainless steel knives, mechanically sliced into slices, 1.3 to 1.5 millimeters thickness by Lama 220 slicer model Shed Co, Italy. The resulted slices were washed to remove the released starch formed during slicing. The weight of washed slices was $300 \mathrm{gm}$. before frying, The slices were immersed in palm olein vegetable oil at $185^{\circ} \mathrm{C}$ until fried, using pilot fryer, 8 liter capacity, model Bartlett D11E30, Italy. When the oil in the fryer heated to $185^{\circ} \mathrm{C}$, power to the fryer was immediately switched off then the basket containing potato slices was immersed in the oil. The basket was moved out rigorously after 3 minutes from frying in the oil to prevent the sticking of slices together. The weight of fried sample was recorded to calculate the chips yield.Samplesof chips were inspected for defects according to the standards of Frito Lay Company (1999).

\section{The Recorded data,Foliage measurements}

Number of main stems/hill was determined using the average number of main stems per hill after planting.Plant height $(\mathrm{cm})$ was determined using the average height of the main stem of 10 plants at 75 days after planting. Total leaf chlorophyll content $(\mathrm{mg} / 100 \mathrm{~g}$ FW)was determined in the fourth top leaves at 75 days after planting according to (Moran and Porath, 1980) method.

\section{Yield and its component}

Total tuber yield: The tuber yield of each plot was weighed in kilogram and then converted into tons/fed. The suitable tubers for processing per plot were selected, weighted and converted into tons/fed. The number of tubers $/ 10 \mathrm{~kg}$ was determined by taking a random sample of $10 \mathrm{~kg}$ of tubers from the yield of each treatment and then counted. The accepted category is that count $72-112$ tubers in such treatment (Frito Lay Company.1999).Average tuber weightwas determined by dividing the tubers yield/plant by tuber's number as an average of 10 plants, at harvesting time.

Table 1. The main chemicalanalysis of the experimental soil

\begin{tabular}{|c|c|c|c|c|c|c|c|c|c|c|c|c|c|c|}
\hline \multirow[t]{2}{*}{$\mathbf{P H}$} & \multirow[t]{2}{*}{$\begin{array}{c}\mathrm{EC} \\
(\mathrm{ds} / \mathrm{m}) \\
\end{array}$} & \multicolumn{2}{|c|}{$\begin{array}{c}\text { Soluble anions } \\
(\mathrm{meq} / \mathrm{l})\end{array}$} & \multicolumn{4}{|c|}{ Soluble cations(meq/l) } & \multicolumn{7}{|c|}{ Available nutrients(ppm) } \\
\hline & & $\mathrm{Cl}^{-}$ & $\mathrm{HCO}_{3}^{-}$ & $\mathrm{Na}^{++}$ & $\mathrm{Ca}^{++}$ & $\mathbf{M g}^{++}$ & $\mathbf{K}^{++}$ & $\mathbf{N}$ & $\mathbf{P}$ & $\mathbf{K}$ & Zn & $\mathbf{C u}$ & Mn & $\mathbf{F e}$ \\
\hline 7.99 & 2.88 & 6.9 & 3 & 12.9 & 6.9 & 7.07 & 1.02 & 11 & 10 & 152.9 & 0.87 & 1.02 & 1.88 & 3.7 \\
\hline
\end{tabular}


Dry matter (\%) was determined by drying the tuber sample slices at $70{ }^{\circ} \mathrm{C}$ for $24 \mathrm{hrs}$ until a constant weight by dividing the dry weight/the fresh $\times 100$ (Haase, 2003). Specific gravity was determined using the method described by Dinesh et.al., (2005)

\section{Chemical composition of potato}

75 days after planting the forth top leaves of 10 random plants per plot were carefully detached, packed in paper bags. The collected samples were washed with tap water, distilled water, oven dried at $65^{\circ} \mathrm{C}$ for $72 \mathrm{hrs,}$ then grounded in a mill and stored for the elemental analysis. Powder of leaf material was wet digested with $\mathrm{H}_{2} \mathrm{SO}_{4}-\mathrm{H}_{2} \mathrm{O}_{2}$ digest (Lowther, 1980) for the following determinations. Leaf total $\mathrm{N}$ content was determined colorimetrically, 75 days after planting using the Nessler's method (Chapman and Pratt, 1978).Leaf total $\mathrm{K}$ content was determined photometrically, 75 days after planting using the flame photometer method (Jackson, 1973).Tuber total N content was determined using standard methods described by Ryan et.al., (2001). Tuber total K content was determined using standard methods described by Ryan et.al. (2001).

\section{Quality character}

Starch content (\%) was determined using the method described in A.O.A.C (1980) on dry matter basis. Total sugars contents (\%) was determined using method outlined byDubbois, et.al.,(1956) fresh weight bases. Reducing sugars content (\%) was determined using Dubbois et. al., (1956) method on fresh weight basis. Chips defect evaluationwas calculated by showing the size limits $(1 / 2 \mathrm{~cm})$ for sugar browning and defects using chip- check chart method to determine the internal, external and undesirable color defects and dividing the defects to three categories; the first green from $0-8 \%$ defects are acceptable potato chips, the second yellow $8-15 \%$ defects are acceptable potato chips but with discarding the percentage over $8 \%$ and the third red $>15 \%$ defects are rejected and not suitable for processing according to (Frito Lay Company,1999).

\section{Soil analysis}

At planting time, soil samples were taken by soil tube method (Richards 1972) at 0-30 cm depth. Soil pH was measured in 1:1 (w/v) soil: water suspension using the combined glass electrodes (Jackson, 1973). Total soluble salts or electrical conductivity $(\mathrm{Ec}, \mathrm{dS} / \mathrm{m})$ was measured in L: $1(\mathrm{w} / \mathrm{v})$ soil: water extract using the conductivity meter according to Jackson (1973). Soluble cations $\mathrm{Na}^{+}, \mathrm{Ca}^{++}, \mathrm{Mg}^{++}$, and $\mathrm{K}^{+}$(meq/l) were measured according to Jackson (1973). Soluble anions $\mathrm{Cl}$ - and $\mathrm{HCO} 3-(\mathrm{meq} / \mathrm{l})$ were measured according to Jackson (1973).Available N, P and K in soil were determined using the methods described by Winkleman et.al., (1990). Available $\mathrm{Zn}, \mathrm{Cu}, \mathrm{Mn}$ and $\mathrm{Fe}$ in soil were determined using the methods described by Winkleman et.al., (1990).

\section{Water irrigation analysis}

Water $\mathrm{pH}$ was measured using the combined glass electrodes (Jackson, 1973). Total soluble salts. $(\mathrm{EC}, \mathrm{dS} / \mathrm{m})$ was measured in water using the conductivity meter according to (Jackson 1973).

The collected data were tabulated and statistically analyzed using the analyses of variance method as reported by Snedecor and Cochran (1980).

\section{RESULTS AND DISCUSSION}

\section{Potato Vegetative Characters}

Table (2) showed that vegetative growth characters of potato number of branches/plant, plant height and total chlorophyll content were improved significantly as $\mathrm{K}$ fertilizer rate increased in both seasons. These results indicated that application of K at level $120 \mathrm{~kg} / \mathrm{fed}$, with bio-fertilizer gave the highest mean values of number of branches at first season but addition of bio-fertilizer with $\mathrm{K}$ mineral fertilizer at 80 or $100 \mathrm{~kg} \mathrm{~K} /$ feddan was equivalent to the application of $\mathrm{K}$ fertilizer only at 120 $\mathrm{kg} / \mathrm{fed}$, or with application of bio fertilizer at second season .Application of potassium at $100 \mathrm{~kg} / \mathrm{fed}$, in combination with bio-fertilizer gave the same effected of the application of $\mathrm{K}$ fertilizer at $120 \mathrm{~kg} / \mathrm{fed}$. only or with application of bio fertilizer at first season .Also, $\mathrm{K}$ level at $120 \mathrm{~kg} / \mathrm{fed}$. Additionof bio-fertilizer gave the highest mean value of plant height at second season. The highest mean value of chlorophyll content was recorded at $120 \mathrm{kgK} / \mathrm{fed}$. only or with application of bio-fertilizer at first season, but the highest value was recorded at $120 \mathrm{kgK} / \mathrm{fed}$. with application of biofertilizer second season. These results are in agreement with those found by Ahmed etal., (2009) who reported that application of potassium improved plant growth characters compared with untreated plants. AbdElMouty et.al.,(2001) reported that Bio-fertilizers application affected plant growth of potatoes. Moreover Fawzy et.al.,(2012) reported that bio-fertilizer has beneficial return to increase population of soil microorganisms especially in the surface layer of root Rhizosphere that create substances which stimulate plant growth.

\section{Potato yield, its component characters and accepted potato yield for processing $\%$}

Table (3)cleared that application of potassium fertilizer only at $120 \mathrm{~kg} / \mathrm{fed}$, or with bio-fertilizer gave the highest mean value of tuber weight and average of tuber weight, and also, gave the same effect of $\mathrm{K}$ 


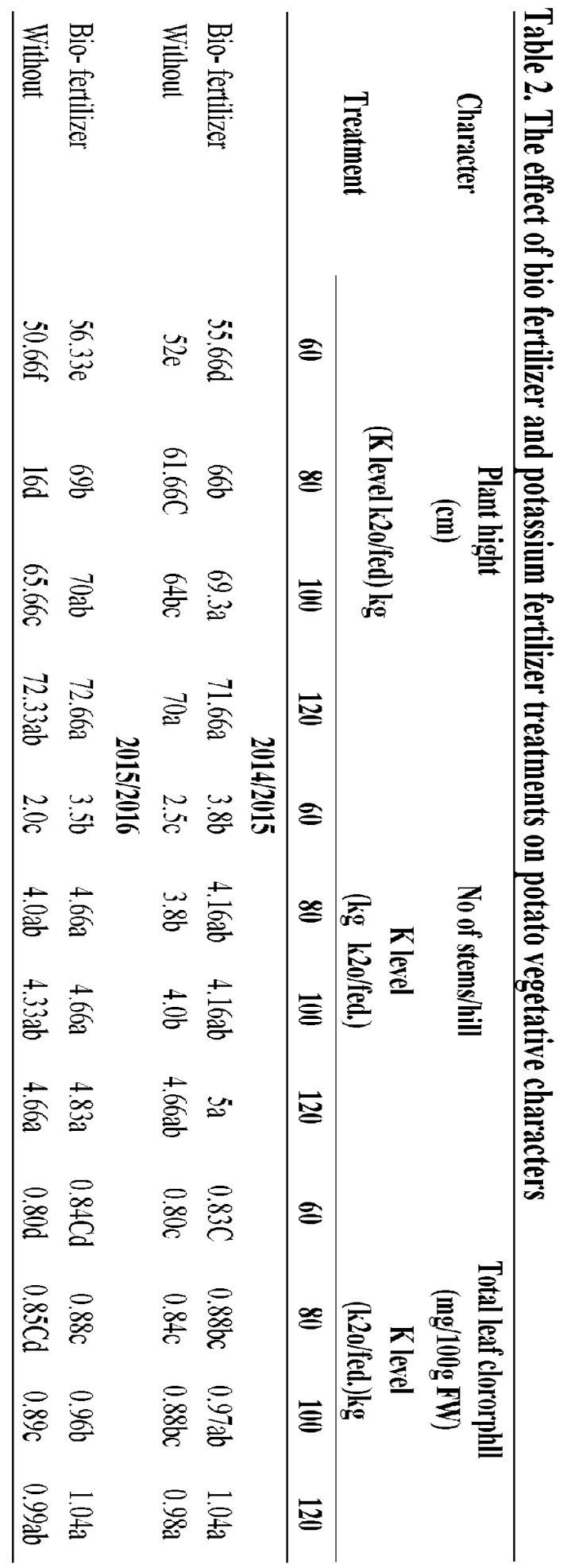




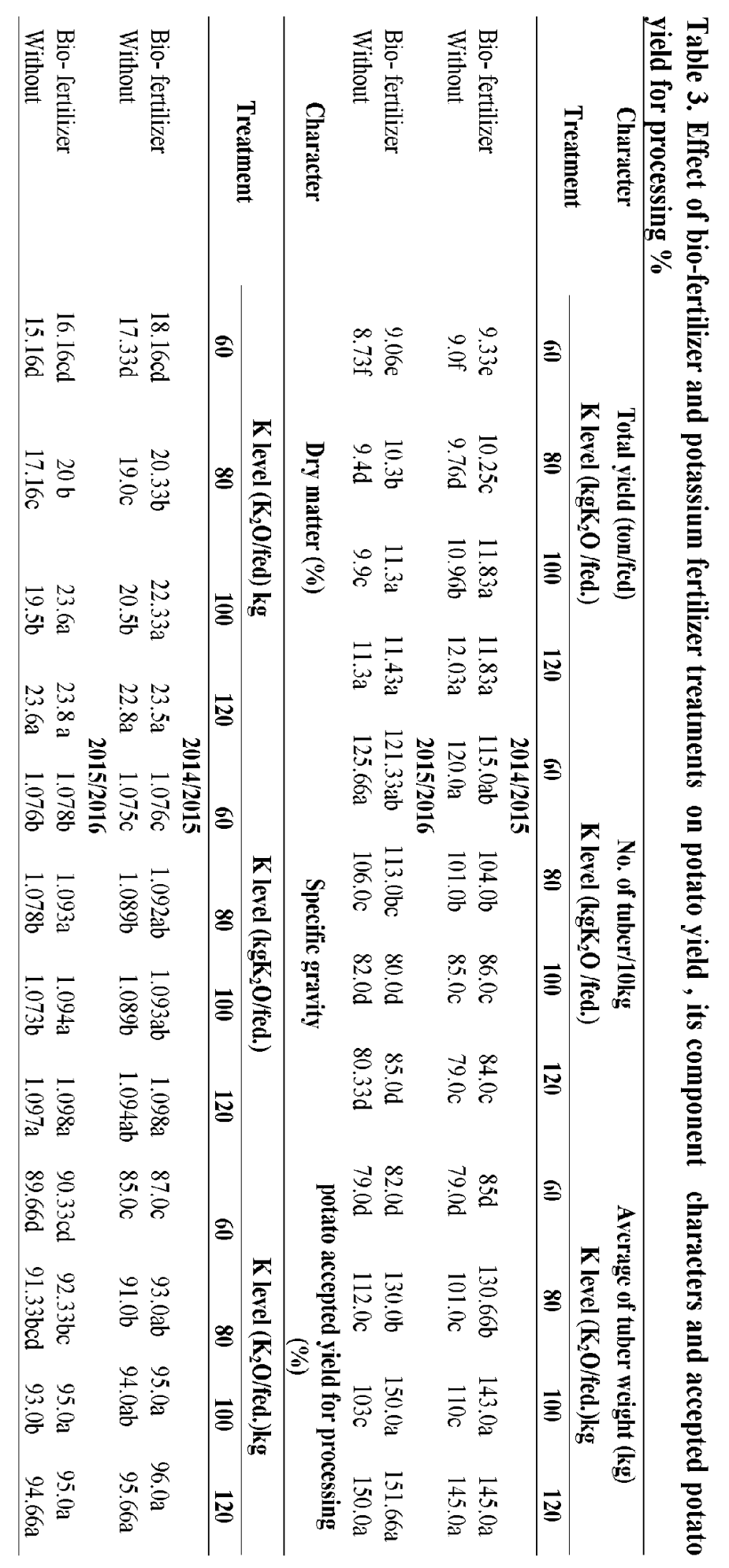


fertilizer at $100 \mathrm{~kg} / \mathrm{fed}$.with application of bio fertilizer at two seasons.Application of $\mathrm{K}$ fertilizer at $60 \mathrm{~kg} / \mathrm{fed}$. only or with bio fertilizer produced highest number of tuber $/ 10 \mathrm{~kg}$. The highest value of dry matter at level 120 $\mathrm{kg} \mathrm{K} / \mathrm{fed}$, only or with application of bio-fertilizer. The same effect of the application of $\mathrm{K}$ fertilizer at $100 \mathrm{~kg}$ $\mathrm{K} /$ fed. with application of bio-fertilizer at the two seasons. The highest mean value of specific gravity at level $120 \mathrm{~kg} \mathrm{~K} /$ fed. with application of biofertilizer was recorded at first season but at second season 100 and 80 $\mathrm{kg} \mathrm{K} /$ fed with application of biofertilizer gave the same effect of the application of $\mathrm{K}$ at $120 \mathrm{~kg} \mathrm{~K} / \mathrm{fed}$, only or with application of bio-fertilizer. These results agree with those found byArafa et.al.,(2012) who indicated that tuber yield measured as tubers yield $(\mathrm{kg})$ per plant and total yield (kg)per plant and total yield(ton/fed.)were significantly increased with increasing potassium fertilizer rate. Bio-fertilization exerted positive effects in this respect. An addition of effective microorganisms in both seasons significantly increased tuber yield per plant and tuber yield per fed. An increase in potato yield as indicated in the present investigation due to applying potassium was reported by Radwan et.al.,(2011) who indicated that potassium fertilization in potato resulted significant increase in tuber yield. The role of potassium in increasing the yield and its components might be attributed to its functionin plants which includes energy metabolism and enzyme activation on exchange rate and nitrogen activity as well as enhanced carbohydrates application enhanced the stomatal resistance coupled with reduced transpiration rate and increased relative water content, thus, may improve water storage capacity of the cells and providing favorable conditions for better yields (Umar and Bansal 1995). Concerning the effect of effective microorganisms, Lin (1991) indicated that soils treated with microorganisms become more friable, less compact and better drained. This provides a more favorable environment for crop, growth and tuber production. The enhancing effect of microorganisms on yield and its component may be attributed to one or more of the following factors: improving root growth and functions and enhancing mineral uptakein the plant (Stancheva et.al.,1995), production the phytohormonesindole: acetic acid, gibberellins and cytokinin, also reduce of abscic acid.Thesephytohormones, particularly IAA,play an essential role in plant growth stimulation (Kawther et.al., 2002) and producing amino acids as well as phenolic compounds (EL-Morsi et.al.,2000). The increase of tuber numbers and tuber dry weight $(\mathrm{g})$ per plant may be due to microorganisms application stimulated plant roots, absorption of nutrients and photosynthesis process which led to produce vigorous plants, numerous tubers, bigger tuber size and total tuber yield (Hammad and Abdel-Ati 1998).

While, the percentage of accepted tubers from processing increased gradually and significantly as potassium level was increased in both seasons. Adding $\mathrm{K}$ at the rate of $120 \mathrm{~kg} \mathrm{~K} / \mathrm{fed}$. only or with application of bio-fertilizer gave the highest accepted percentage of tubers for processing. Also, $100 \mathrm{~kg} \mathrm{~K} / \mathrm{fed}$, with application of bio-fertilizer gave equal effect. These results may be accepted on the basis than $\mathrm{k}$ resulted in a sturdy plant and in turn, sturdy tubers, which can tolerate miss handling browses and cracks during harvesting. In addition, it increased the tuber content of soled and specially starch and handling the crop in the field. It was recorded by Khan et.al.,(2010) that K enhanced potato tuber yield and also improved the quality of the produced potato compared with the low potassium rate, the higher $\mathrm{K}$ rate increased the yield of medium $(82-60 \mathrm{~mm})$ and oversized $(<60 \mathrm{~mm})$ tubers by approximately 15 and $40 \%$, respectively and both categories of tuber sizeses are accepted for processing (Tawfik, 2001). Similarly McDole (1978) and Satyanarayana and Arora (1985) reported that insufficient $\mathrm{K}$ results in reduced yield and smaller tubers which are rejected from processing.

\section{ChemicalComposition of Potato Showed}

Table (4) that Potassium fertilizer levels only or with bio fertilizer had highest significant effect for leaves and tuber elements. Potassium level at $60 \mathrm{~kg} / \mathrm{fed}$ only gave the highest mean value of $\mathrm{N}$ concentrations in leaves and roots at two seasons. On the other hand, potassium only at $120 \mathrm{~kg} / \mathrm{fed}$, or with application of bio-fertilizer gave the highest mean value of $K$ concentration in leaves in both seasons. Addition of potassium at $100 \mathrm{~kg} / \mathrm{fed}$, with application of biofertilizer gave the same effect and highest mean value of $\mathrm{K}$ concentration in leaves at first season,while, potassium level at $120 \mathrm{~kg} \mathrm{~K} / \mathrm{fed}$, with application of bio-fertilizer gave the highest mean value of potassium concentration in tuber at first season but at second season potassium fertilizer only at $120 \mathrm{~kg} \mathrm{~K} /$ fed,only or with applicationof bio-fertilizer gave the highest mean value of K concentration in tuber. Arafa et.al., (2012) reported that inoculation potato plants with effective microorganisms significantly increased the percentage of nitrogen and insignificantly increased potassium percentage in potato tuber as compared with untreated plants,Afify and Bayoumy (2001) reported that the increase in tubers potassium content might be possibly due to the role of microorganisms in supplying great amounts of both water-soluble and amorphous potassium which was reflected in plant up take. 


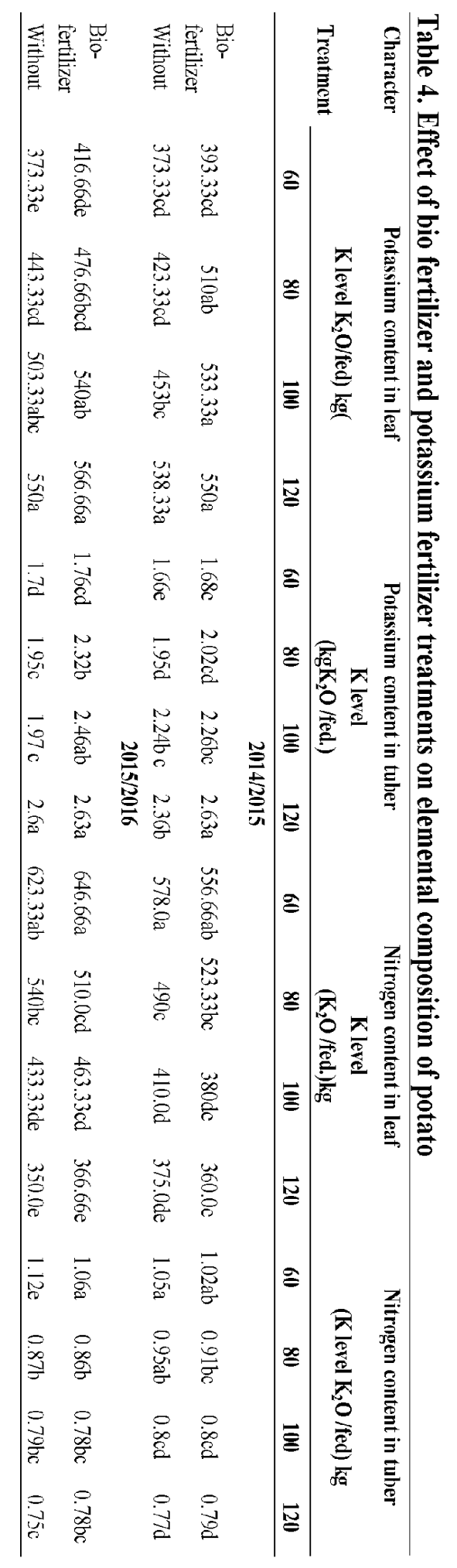




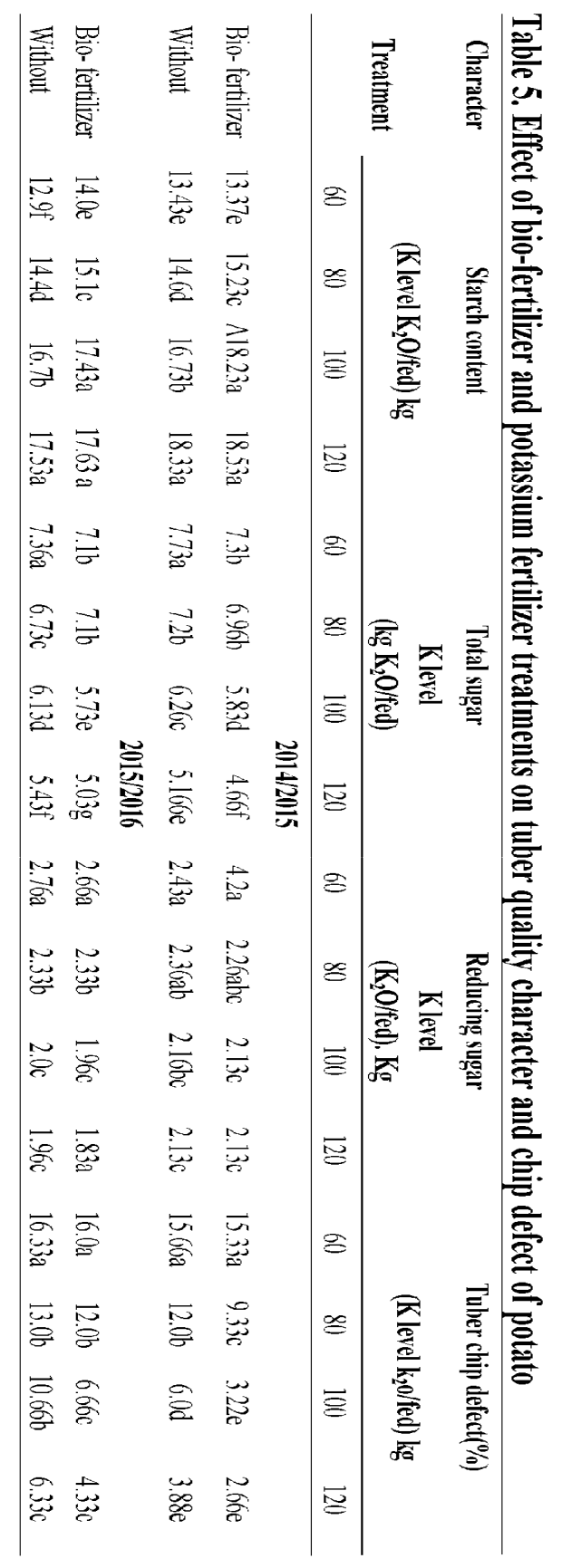


On the other hand, Ahmed et.al., (2009) reported that there was no significant interaction between $\mathrm{K}$ - addition and biofertilization on $\mathrm{N}$ and $\mathrm{K}$ uptake by shoots.the highest $\mathrm{K}$ content in tubers was recorded with the highest level of potassium sulphat.

\section{Tuber quality character and chip defect of potato}

Table (5) showed that Potassium fertilizer only or with application of bio fertilizer had highly significant effects on most studied characters with only exception reducing sugar content in thetwo seasons. The highest mean value of starch content in tuber was recorded at $120 \mathrm{~kg} \mathrm{~kg} / \mathrm{fed}$,only or with application of bio-fertilizer. Potassium rate at $100 \mathrm{~kg} / \mathrm{fed}$,with application of biofertilizer gave the equal effect in two seasons. Potassium fertilizer only at $60 \mathrm{~kg} \mathrm{~K} / \mathrm{fed}$, gave the highest mean value of totall sugar content in tuber at two seasons,while, potassium fertilizer only at 60 $\mathrm{kg} / \mathrm{fed}$, or with bio-fertilizer application gave the highest mean value of reducing sugar content in two seasons.

These results are in agreement with found byBansal and Trehan (2011) who reported that $\mathrm{K}$ application decreased total sugar. Arafa et.al., (2012) noted that increase potassium fertilizer rate from 40 to $80 \mathrm{~kg}$ $\mathrm{K} / \mathrm{fed}$, decrease sugar content in potato tuber. They also,added that inoculation of potato plants with effective microorganisms increase soluble sugars in potato tuber.Rai et.al., (2010) indicated that potassium influence reducing sugar content, Mohamed (2007) reported thatapplication of microorganism decreased total carbohydrates content. Abdel Salam and Shams (2012) noted that biofertilization increased starch content. Ahmed et.al., (2009) found that starch content in tuber potato showed positive responses to increasing mineral K levels. BansalandTrehan (2011) found that K fertilizer application decreased total and reducing sugar. On contrary,Rajanna et.al., (1987) found that potassium fertilizer increased total and reducing sugar.Rajanne et.al., (1987),Sahota et.al., (1988),EL-Gamal (1980), AL-Moshileh (2005) and Bansal and Trehan(2011) reported that $\mathrm{K}$ application increased tuber starch content. On the contrary Terman(1950) pointed that there was a consistent decrease in the starch content of potato tuber with increase in the rate of $\mathrm{K}_{2} \mathrm{O}$ application.

Accumulation of soluble sugars and decrease of starch in potato tubers are the cause of dark colored potato chips which occur under low potassium nutrition level (Perrenoud 1993). Moreover, K application decreased reducing sugars and improve lighten chip color. Anon (2005)andBansal and Trehan (2011) found that $\mathrm{K}$ fertilizer application decreased reducing sugar and improve chips color during procession. In potatoes, reducing sugars are involved in the non-enzymatic browning reaction, known as the Maillard reaction (Ellis,1959), and thus the amount of reducing sugars (glucose and fructose)determines the processing potential of potatoes in terms of frying colour (Brown et.al.,1990; Burton, 1989).

Crisps prepare from potatoes having a higher amount of reducing sugars turn brown and become unacceptable to consumers (Ezekiel et.al.,2003). Because of the Maillard reaction occurs between reducing sugars and amino acids during heating, fried potato products acquire a dark color and a bitter taste and become un acceptable to consumers (Burton,1989).

Kumar et.al., (2007) noted that reducing sugars and crisps color are positively correlated

Over while, increasing $\mathrm{K}$ level reduced tuber chips defects in both seasons. The lowest level of chips defects was also found at the level $120 \mathrm{kgK} / \mathrm{fed}$. only or with application of bio-fertilizer. Potassium at 100 $\mathrm{kg} / \mathrm{fed}$. with application of bio fertilizer gave the same effect in two seasons.

Kunkle and Holstad (1972) found statistical effect for K level on chip color. Anon., (2005) also, indicated that $\mathrm{K}$ application improved chip color score. Bansal and Trehan (2011) reported that $\mathrm{K}$ fertilizer improves quality parameters of tuber processing. Crisp quality is a collection of many characters and color is one of the most important .In general, yellowish brown (Burton et al., 1992), uniform light golden (Stevenson et al., 1964), and lighter colored crisps are preferred. Crisps colors between grade 1 (white cream) and grade 3 (dark tan) are commercially acceptable (Amoros et. al., 2000). Dark brown crisps may have an undesirable flavor and generally are unattractive to the consumers (Stevenson et. al., 1964). Arafa et.al.,(2012) indicated that the inoculation of potato plants with effective microorganisms improved the potato quality and all tuber quality characteristics. The specific gravity is a measure of quality in potato tuber which is related to the dry matter contents in the tubers. The specific gravity was more in potato tubers harvested from potassium treated plants (Malik 1995). Potatoes with high specific gravity are preferred for preparation of chips and French fries. Mohamed (2007) reported that application of microorganisms increased significantly TSS\% but decreased total carbohydrates content.

\section{REFERENCES}

Abdel Aal, Z.S., A.A.KhalfAlla ,M. AL-Shal, M. and Abd al-Qader. 1977. Vegetables production Part 2.Dar.ALMadboat.AL-Jadida, Pubksher Alexandria, A.R.E.pp.1557. 
Abdel-Mouty, M.M., A.H. Ali and F.A. Rizk. 2001. Potato yield as affected by the interaction between bio and organic fertilizer .Egypt. J. Appl. Sci., 16 (6): 267-286.

Abdel-Salam ,M.A and A.S.Shams. 2012. Feldspar $-\mathrm{K}$ fertilization of potato (Solanum tuberosum L.) augmented by biofertilizer. American- Eurasian J. Agric. Environ. Sci., 12 (6):694-699.

Afify, A. H. and S. M.M. Bayoumy. 2001. Effect of certain silicate bacteria on primary silicate minerals. Egypt $\mathrm{J}$. Agric Sci., Mansoura Univ., 26(5): 3111-3125.

Ahmed,A.A.1994. Effect of some agricultural practices on potato production from seed tubers and seeding tubers. M.Sc. Thesis Ain Shams Univ., pp:100.

Ahmed A.A., M.M.H.A. El-Baky, F.S.A. El-Aal, and M.F. Zaki. 2009. Comparative studies of application both mineral and bio-potassium fertilizers on the growth, yield and quality of potato plant .Res. J. Agric.Biolog. Sci. 5(6):1061-1069.

Al-Moshileh, A. M., M. A. Errebhi and M. I. Motawei. 2005. Effect of various potassium and nitrogen rates and splitting methods on potato under sandy soil and arid environmental conditions. Emir. J. Agric. Sci. 2005. 17 (1): 01-09.

Amoros, W., J. Espinoza and M Bonierbale. 2000. Assessment of variability for processing potential in advanced potato populations. CIP, Lima.

Anon, ymous. 2005. Annu. Rep., on evaluation of Potassium fertilizer sources on yield and quality of potato, Potash Res. Inst. India, Gurgaon.

A.O.A.C. 1980.Official Methods of Analysis, Association of Official Agricultural Chemists, Bed., Washington, D.C.P.1018.

Arafa,A.A., S.F.M.Hussien and S.G.Hager Mohamed. 2012.Responce of tuber yield quantity and quality of potato plants and its economic concederation to certain bioregulators or effective microorganisms under potassium fertilization. J.PlantProduction, Mansoura Univ., Vol. 3(10): 131-150.

Bansal, S. K. and S.P. Trehan.2011. Effect of potassium on yield and processing quality attributes of potato. India Karnataka J. Agric. Sci., 24 (1): 48-54.

Brown, J., G.R. Mackay, H. Bain, D.W. Griffith and M.J. Allison. 1990.The processing potential of tubers of the cultivated potato, Solanumtuberosum L., after storage at low temperatures. 2. Sugar concentration. Potato Research 33: 219-227.

Burton, W.G. 1989. The Potato. John Wiley and Sons, New York, 742 pp.

Burton, W.G., Es. A. Van and K.J. Hartmans. 1992. The physics and physiology of storage. In: Harris PM (ed) The potato crop, 2nd edn. Chapman and Hall, London, pp 608-727.
Chapman, H.D. and P.F. Pratt. 1978. Methods of analysis for soils, plants and waters.Univ. ofcolifornia, Div. Agric. Sci., Priced publication.Cunningham CE and Stevenson FJ. 1963. Inheritance of factors affecting potato chip color and their association with specific gravity. Am Potato $\mathrm{J}$ 40(6):253-265.

Deka,N.C. and T.C.Dutta.2000. Effect of potassium on yield and economics of potato cultivation in an acidic soil of Assam.j.Potassium Res., 16:77-99.

Dinesh, K., R. Ezekiel, B. Singh and I. Ahmed. 2005. Conversion Table for specific gravity dry matter and starch content from under water weight of potatoes grown in North India plains. Potato J., 32 (1-2) 79-84.

Dubbois, M.,K.A. Gilles, J.K. Hamilton, P.A. Rebers and F. Smith. 1956. Calorimetric method for determination of sugars and related substances. Analytical chem.28:250356.

El Gamal, A. M. 1980.Studies on the relationship between some fertilization treatments and the deterioration and improvement of seed potato production.Faculty of agriculture, Alexandria Univ.

Ellis, G.P.1959. The Maillard reaction. Advances Carbohydrate Chemistry., 14: 63-134.

EL-Morsi, E.A., G.F.Abdel-Naem, E.S. Shaker and M.A.Ghazy. 2000. Influence of bio fertilization on total phenolic compounds and antioxidative activity potato tubers (Solanumtuberosum,L.). Arab Universities J.ofAgric.Sci., 8 (1):1:18.

Ezekiel, R., B .Singh and D. Kumar. 2003. A reference chart for potato crisps colour for use in India. J. Indian Potato Assoc 30:259-265.

Fawzy,Z.F, Z.S.EL-Shal, L.Yunsheng, O.Zhu and O.M.Sawan. 2012. Response of agric (Allium Sativum,L.) plant to foliar spraying of some bio stimulants under soil condition . J .Appl .Sci., Res., 8:770-776.

Frito Lay Company. 1999. Potato sending Manual. Operations quality system department. Leicester, United kingdom.

Jackson, M. L. 1973. Soil chemical analysis.Prentice Hall, of India private Limited New Delhi.

Haase, N.U. 2003.Estimation of dry matter and starch concentration in potatoes by determination of under water weight and near infra red spectroscopy. Journal of Potato Research, Netherland, 46 (3-4): 117-127.

Hammad, A.M.M. and Y.Y.Abdel-Ati. 1998. Reducing of nitrate and nitrite contents of potato tubers via Biofertilization with AzospirillumandVAMycrrohyzal Fungi. Egypt J. Agic. Sci., Mansoura Univ., 23(6):2597- 2601.

Kawthar, A.E.R., S.M. Selim and S.A. Nasr. 2002. Nitrate and nitrite accumulation in potato tubers in relation to mineral nitrogen and biofertilization. Egypt Annals Agric. Sci. (Cairo), 47(1):107- 122.

Khan, M. Z., M. E. Akhtar, M. N. Safdar, M. M. Mahmood, S. Ahmad and N. Ahmad. 2010. Effect of source and level of potash on yield and quality of potato tubers. Pak. J. Bot., 42(5): 3137-3145, 2010. 
Kumar, P., S. K. Pandey, B. P. Singh, S. V. Singh and D. Kumar. 2007. Influence of Source and Time of Potassium Application on Potato Growth, Yield, Economics and Crisp Quality. Potato Research (Indian). 50:1-13.

Kunkle,R., and N. Holstad. 1972. Potato chip color, specific gravity and fertilization of potatoes with N-P-K. Am Potato J 49:43-62.

Lalitha, B.S., K.H.Nagaraj, K.C.Lalitha and T.N.Anand.2000. Levels of potassium and sulphur on concentration and uptake of nutrients by true potato seed (TPS) and seed tuber. Current Research Unv., Agric., Sci., Banglore,29:82-83.India.

Lin, D.L. 1991. Nature farming in Taiwan: Effect of EM on growth and yield of paddy rice. p. 125-131. In J.F. Parr, S.B. Hornick, and C.E. Whitman (ed.) Proceedings of the First International Conference on Kyusei Nature Farming. U.S. Department of Agriculture, Washington, D.C., USA.

Lowther, J.R. 1980.Use of single H2SO4-H2O2 digest for the analysis of PimusRadiata needless. Comm. Soil Sci. Plant Analysis, 11, 175-188.

Malik, N.J.1995. Potatoes in Pakistan: A Hand Book. Pak Swiss Potato Development Project, Pakistan Agricultural Research Council, Islamabad. ISBN 969-8301-00-3.

Marschner, H. 1997.Mineral nutrition of higher plants.2nd ed. Acad. Press Inc., London.

McDole, R.E.1978. Potassium fertilizer tails with potatoes in coarse textured soils in southerneastern Idaho. Amer. Potato J., 55: 161:170.

Mohamed F., F.E. 2007.The effect of growth regulators and partial replacement of mineral fertilizers by bio-fertilizers on botanical characters of caraway (CarumcarviL.) and anise (PimpinellaanisumL.) plants. Ph.D. Thesis, Fac. Agric.Fayoum Univ., Egypt.

Moran, R. and D. Porath. 1980. Department of botany, The Geovge.S.Wise faculty for life sciences, Tel Aviv university, Ramat Aviv, Israel plant physiol 65:478-479.

Perrenoud,S.1993. Potato:fertilizers for yield and quality., International Potash Institute,Bern.,pp:94.

Radwan, E.A., Z.S.A. El-Shall and R.A.M. Ali. 2011. Effect of potassium fertilization and humic acid application on plant growth and productivity of potato plants under clay soil. J. Plant Production, Mansoura Univ. 2(7):877-890.

Rai, G.K., P.K. Rai, S.K. Singh, A.P. Rai and A.K. Khokhar. 2010. Effect of potassium on yield and quality of potato (SolanumtuberosumL.) tubers. Environ. Ecology. 28(1B):694-696.
Rajanne, K. M., K. T. Shivasankar and K.S. Krishnappa. 1987. Effect of different levels of nitrogen, phosphorus and potassium on growth, yield and quality of potato. South Indian Horticulture 35:347- 355.

Richards, L. A. 1972. Diagnosis and improvement of saline and alkali soils.U.S.Salinity Laboratory staff, Agriculture Handbook Book No.60.

Ryan, J, G. Estefan, and A. Rashid. 2001. Soil and Plant Analysis Laboratory Manual. 2nd ed. ICARDA and NARC, Aleppo, Syria.

Sahota, T. S., H. Singh, S. S. Cheema and J. S. Grewal. 1988. Potassium nutrition of potato in India. Potash Review, No. 3, 10pp.

Satyanarayana,V., and P.N. Arora. 1985. Effect of nitrogen and potassium on yield and yield attributes of potato (var. KufriBahar). Indian J Agron 30:292-295.

Saurbeck, B.C. and H.M.Helal. 1990. Factor affecting the nutrient efficienty of plant. Genetic Aspected Of Plant Mineral Nutrion .Martinus Nijhoff,,Dordtecht,pp.361372.(c.f.Melven(2002).

Snedecor, G.H. and W.C.Cochran. 1980. Statistical Methods.7th ed. Lowa State Univ. Press. Ames, Iowa, USA.

Spooner, D.M. and J.B.Bamberg. 1994. Potato genetic resources : sources of resistance and systematics .Amer. Potato J.71:325-338.

Stancheva, I., I. Dimitrov, N. Kaloyanova, N. Dinev and N. Poushkarov. 1995. Improvement of the nitrogen uptake and nitrogen content in maize (Zea mays) by inoculation with Azospirillum brasilense. Agrochimica, 39: 299-306.

Stevenson, F.J., R.V. Akeley and C.E. Cunningham. 1964. The potato- its genetic and environmental variability. Amer Potato J 41(2):46-53.

Tawfik, A. A. 2001. Potassium and calcium nutrition improves potato production in drip-irrigated sandy soil. African Crop Sci. J. 9:147- 155.

Terman, G. L. 1950. Effect of rate and source of potash on yield and starch content of potatoes. Results over 20-years period.The main Agric. Exp. Sta. Orono, Main Bull.481: 6.

Umar, S. and S.K. Bansal. 1995. Potassium requirement of mustard (Brassica junceaL.) under moisture stress conditions. Plant Physiol\&Biochem, New Delhi, 22(2):130-135.

Watt,B.K. and AL-Merrill.1963. Composition of foods .U.S Dept. Agric . Handbook No.8.190p.

Winkleman, E., R. Amin, W.A. Rice and M.B. Tahir. 1990. Methods manual soil laboratory. BARD, PARC, Islamabad 


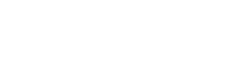

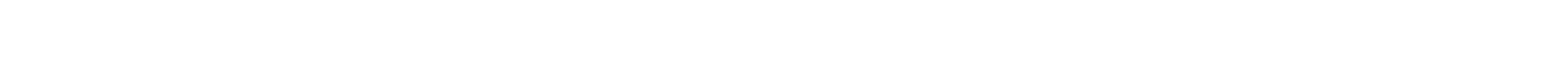 لإنلت البلملس المصنه \\ سعيد لحمد نكي، دينا صلاح الين المسيري، مني محمد يسري جالبر}

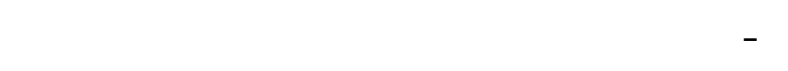

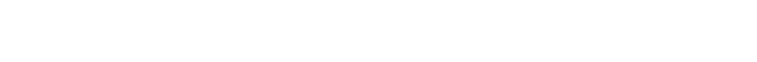

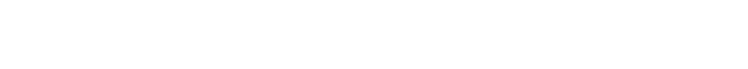

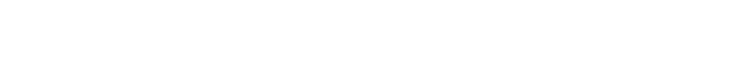

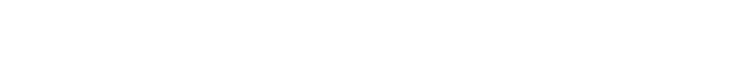

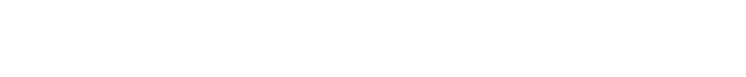

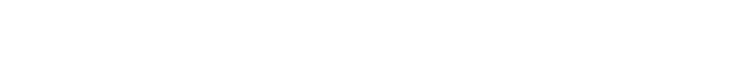
الكليةوالمختزلة.

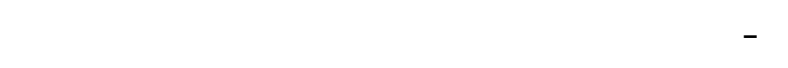

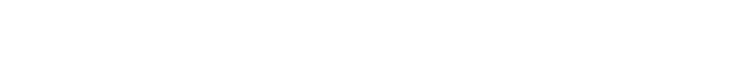

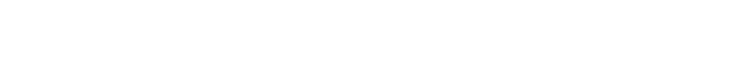

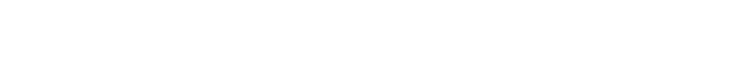

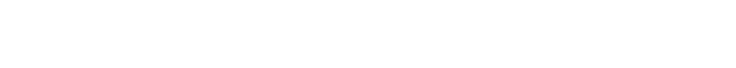
معدل التسميد البوتلسيوم قل من نسبه العيوب التصنيعية

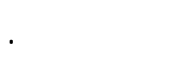

لجريت تجربتنل حقليتنان في المزرعة الخاصة بـ شرركه

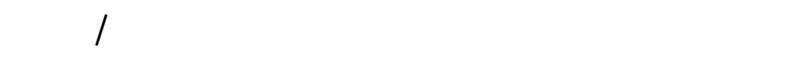

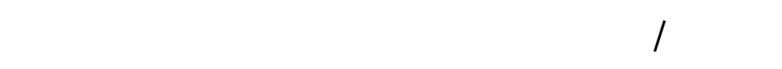

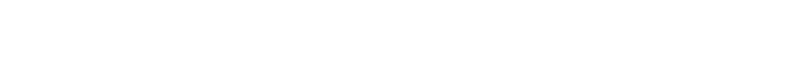
وجوة في البطلس. وكانت أهم النتائج المتحصل عليها هي: I -كان التدلخل بين للسماد الحيويوالبوتلسي معنوي اف اف ي

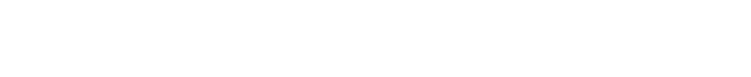

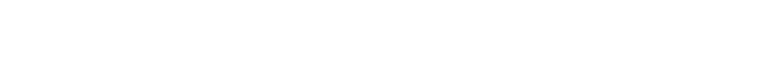

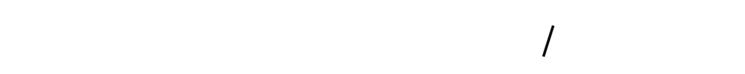

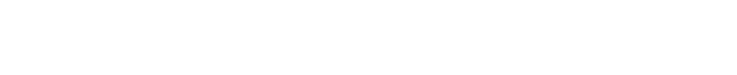

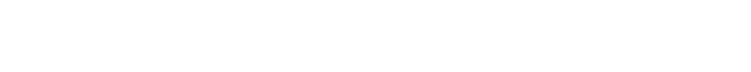

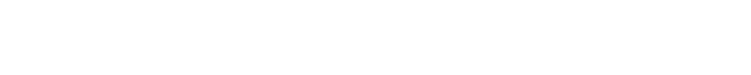
معدل · r ا كجم للفدان مفردا أومع تسميد حيوي اعلي قيمه للكلورفل . 